\title{
Beyond Manpower Planning: a Labour Market Model for the Netherlands and its forecasts to 2006
}

Citation for published version (APA):

Cörvers, F., Heijke, J. A. M., \& de Grip, A. (2002). Beyond Manpower Planning: a Labour Market Model for the Netherlands and its forecasts to 2006. In M. Neugart \& K. Schömann (Ed.), Forecasting Labour Markets in OECD Countries (pp. 185-223). Edward Elgar Publishing.

Document status and date:

Published: 01/01/2002

Document Version:

Publisher's PDF, also known as Version of record

\section{Please check the document version of this publication:}

- A submitted manuscript is the version of the article upon submission and before peer-review. There can be important differences between the submitted version and the official published version of record.

People interested in the research are advised to contact the author for the final version of the publication, or visit the DOI to the publisher's website.

- The final author version and the galley proof are versions of the publication after peer review.

- The final published version features the final layout of the paper including the volume, issue and page numbers.

Link to publication

\footnotetext{
General rights rights.

- You may freely distribute the URL identifying the publication in the public portal. please follow below link for the End User Agreement:

www.umlib.nl/taverne-license

Take down policy

If you believe that this document breaches copyright please contact us at:

repository@maastrichtuniversity.nl

providing details and we will investigate your claim.
}

Copyright and moral rights for the publications made accessible in the public portal are retained by the authors and/or other copyright owners and it is a condition of accessing publications that users recognise and abide by the legal requirements associated with these

- Users may download and print one copy of any publication from the public portal for the purpose of private study or research.

- You may not further distribute the material or use it for any profit-making activity or commercial gain

If the publication is distributed under the terms of Article $25 \mathrm{fa}$ of the Dutch Copyright Act, indicated by the "Taverne" license above, 


\section{Beyond manpower planning: a labour market model for the Netherlands and its forecasts to 2006}

\section{Frank Cörvers, Andries de Grip and Hans Heijke $^{1}$}

\section{l INTRODUCTION}

A well-trained workforce is generally seen as an important precondition for achieving economic growth. But a workforce with higher education does not necessarily imply higher economic growth. The productive value of education is in fact dependent not only on the level of the education but also on the subjects studied and on which occupation is practised with that education (cl. Hartog, 2000). An improved match between the educational background of the workers and the skill requirements of their jobs therefore increases the productivity of the labour force. To the extent that improved better worker-job matches are reflected in higher wages and fit in with the occupational preferences of the workers, the labour force will be more satisfied in its educational and occupational choices.

The allocation process on the labour market is characterized by serious imperfections. Due to the heterogeneous character of the market and a range of inflexibilities of both supply and demand, the labour market could suffer serious mismatch phenomena. While some workers face unemployment, frms may have recruitment problems for ol her skill categorjes. For this reason public policies continuously pay attention to the coordination between the educational system on the one hand, which largely determines the skills supplied, and, on the other hand, the demand in the labour market for the various skill categories.

In the past it was thought that the coordination between the education system and the labour market could be solved through planning. One wellknown approach is the "manpower requirement model" ras applied, for example, by Parnes ( 1962 ), who developed a manpower planning model on 
the basis of the input-output structure of the economy. In this approach the planning begins with the determination of the target growth in the gross national product over a period of several years. From this, after a number of steps, the labour requirements in the various occupations and the educational qualifications which are required for these occupations are determined. The labour requirements are then compared with forecasts of the working population and the flow of graduates from the various types of training into the labour market. The graduate-flow forecasts are compiled with the aid of a student-flow model that describes the flows of students within the educational system. From the differences between future labour requirements and the future working population, allowing for the expected flows from the educational system, it is possible to extract the required information on the extra training initiatives needed to achieve the desired growth in the gross national product.

Various methodological and fundamental objections have been made to the manpower requirements approach. The methodological objections focus in particular on the fixed coefficients, which are used in the forecasting models to translate economic development in to changes in employment differentiated by training and occupation, and on its mechanical concept of labour market functioning, in which there is no place for the working of substitution and other adjustment processes (Blaug, 1967). The fundamental objections are that future developments are not in fact sufficiently predictable, and that an exclusive relationship between job requirements and training is assumed without adequate justification.

These objections, and the lack of sufficient statistical data for the estimation of the forecasting models, led to the rejection of the planning concept. A flexible approach to education was advocated, one which would enable an adequate response to uncertain future developments. According to the latter concept, initial training courses should be broadened so that each could lead to a broad range of occupations. Any discrepancies which might arise between specific, and mutable, job demands and the qualifications of workers would have to be dealt with by means of short training courses and on-the-job training.

The broader scope of initial education courses would speed the matching process in the external labour market, which would lower the search costs for both sides of the market, with the ultimate result that the visible surpluses and shortages of workers with a particular educational background should become smaller. However, if all graduates were to find the job which corresponded best to their capabilities, the less vocation-specific character of these training courses would also result in a poorer average match between the occupation-specific job requirements and the knowledge and skills of those filling the jobs. which would lead to lower productivity in car- 
rying out their functions. Firms wishing to reverse this loss of productivity would have to provide supplementary training for the workers concerned. Increased market efficiency is thus achieved at the price of reduced economic effectiveness in the form either of lower productivity or of higher adjustment costs. In such a situation one has to seek the optimal trade-off between llexibility and productivity or lower adjustment costs (de Grip and Heijke, 1991; Heijke and Borghans, 1998). The flexibility concept would thus have to be implemented within certain limits, meaning that optimal labour market relations would not exclude a degree of market segmentation by education and occupation. The rigidity of the relative wage rates, the high cost of adjustment and the substantial amount of time required for the supply of labour to adapt to changes in demand, because of the length of training courses in initial education, would in this situation continue to be an impediment to the achievement of a perfect match between demand and supply.

As a result of the failings of the macroeconomic policy that was put into place to counter the results of the oil crisis in the 1970 s, interest in improving the adaptability of the supply side of the economy has increased. The process of industrial restructuring and renewal had to be promoted and the working of the market generally stimulated. It was no longer thought that a policy of direct intervention was required to ensure the correspondence of the education system to the labour market, but rather that the provision of adequate information would make the labour market more transparent for those choosing a course of study and others investing in education. This transparency would enable the supply of labour to be more responsive to changes on the labour market. It would then automatically conform better to the new employment opportunities. Moreover, the labour market forecasts give firms an indication of the future risk of labour recruitment problems for the various skill categories, which enables them to anticipate future shortages, for example, by internal training and outfow reduction policies for categories of workers for which future shortages are forecast. This development is evident in the completely changed role of manpower forecasting in the various countries where occupational and/or educational forecasts are still made. ${ }^{2}$

This chapter describes the forecasting model of the Research Centre for Education and the Labour Market (ROA), which has been developed for making forecasts about the Dutch labour market. Every two years ROA compiles forecasts of changes in the labour market in the Netherlands in the medium term, differentiated by a large number of economic sectors, occupational classes and types of education. The chapter aims in particular to describe the basic principles and structure of ROA's forecasting approach and to illustrate the labour market forecasts based on this 
approach for the various types of education and occupation up to the year 2006, which were published at the end of 2001 (ROA, 2001).

The remainder of this chapter is structured as follows. Section 2 first discusses the basic principles underlying ROA's labour market forecasts. In addition to these more general principles we deal with two important characteristics of the forecasting model which attempt to counter the fundamental and methodological criticisms of traditional manpower planning models: the substitution of workers with different educational backgrounds in an occupational field and the related issue of the occupational and educational classifications used. Section 3 discusses the various demand and supply models, which refer to the expansion demand, substitution demand, replacement demand and the inflow of newcomers on the labour market, respectively. Furthermore, in this section the "labour market gap indicator", which is central in ROA's labour market forecasts, is defined. Section 4 describes the expected upgrading of the skill structure of labour demand by presenting the 'expansion demand' forecasts by educational level up to the year 2006 . This section also presents the various components of the changes in employment by educational level. Section 5 gives an overview of students' prospects by type of education up to the year 2006 . Section 6 presents the conclusions.

\section{BASIC PRINCIPLES OF THE LABOUR MARKET MODEL AND ITS USE}

\subsection{Basic Principles}

ROA compiles forecasts of changes in the Dutch labour market in the medium term at a relatively low level of aggregation. ${ }^{3}$ The most recent forecast for the period $2001-6$ is broken down into 13 economic sectors, 127 occupational groups and 104 types of education. A number of basic principles are taken into account when compiling these highly differentiated. forecasts, principles which counter the fundamental and methodological criticisms of early manpower planning approaches. These basic principles are the following:

1. The forecasts are limited to the medium term, that is, to a period of about five years. Within this horizon the changes on the labour market are less uncertain than in the long term, where the uncertain results of the emergence of substitution and other adjustment processes can be decisive, especially where the discrepancies between demand and supply may be extremely large. A forecast period of five years is, moreover, sufficiently 
long to produce useful labour market information for those who are investing in a course which will last for a number of years. However, short-term forecasts for the coming year or two-year period may be important in recruiting personnel, both for short-term training courses and other shortterm labour market programmes and for preparing people to enter the workforce. At present ROA also makes short-term forecasts.

2. In place of fixed coefficients for the occupational and training structure of employment, explanatory models are used to describe the changes in both structures over time. This should also be attempted as regards the flows within the education system, the participation of graduates in employment and the replacement demand. The forecasting models would then be more theoretically justifiable, which would make forecasting with these models less of a black-box affair.

3. The theoretical framework which underlies the forecasting models incorporates both ex ante and ex post substitution processes in the forecasts of the labour market situations for the various types of education. The $e x$ ante substitution processes refer to the demand-led substitution between types of education due, for example, to the upgrading of the skill requirements for a particular occupation, whereas ex post substitution refers to shifts in the educational structure of employment in an occupation due to the initially forecast gaps between demand and supply for the various types of education (see Section 2.2).

4. No detailed comparisons of demand and supply are made for each forecasting year, but the forecast itself is limited to giving a general characterization of the relation between demand and supply for categories of education over the whole forecast period. Information intended as guidance for students is limited to a qualitative description of the labour market prospects of these training categories, on a scale from 'good' to "poor". This requires that the education categories be carefully constructed, so that the variation in labour market prospects within each category is as small as possible. ${ }^{4}$ The use of qualitative descriptions prevents the quantitative forecasts from being treated as more precise than is really the case.

5 . The forecasts are repeated biennially. This makes it possible to keep a finger on the pulse, while leaving sufficient time both to evaluate the observed differences between forecasts and the results realized in the market and to use these evaluations to improve the forecasting method. Differences between forecasts and realizations do have a certain tendency to increase over time. Waiting too long to make modifications will not only encourage bad decisions on training and education, the visible mistakes in forecasting will also contribute to a negative image of the value of labour market forecasts.

6. It is important to make as much use as possible of any understanding 
which already exists of the future growth of employment and the flows from the education system into the labour market. In the Netherlands this applies especially to changes in employment in the various sectors of industry, which ROA takes from the CPB Netherlands Bureau for Economic Policy Analysis, and to the flows from the education system into the labour market, which are largely taken from forecasts made by the Ministry of Education, Culture and Science. By using this information, ROA ensures that its labour market forecasts are consistent with the authoritative forecasts that provide the basis in the Netherlands for policy decisions on important social and economic issues. Moreover, this enables ROA to concentrate on developing its own authoritative expertise within the specialized field of the match between education and the labour market.

7. The uncertainties which are associated with labour market forecasts are to some extent mitigated through mapping the labour market risks which a particular choice of training may entail, as a supplement to the forecast of the probability of finding a job. Statistical indicators are developed, for example for the opportunities which a type of education offers of switching between occupations and the sensitivity of the occupations which are relevant for a particular type of education to cyclical fluctuations (cf. Dekker, de Grip and Heijke, 1994).

8. The forecasts made are evaluated periodically (see, for instance, Borghans, van Eijs and de Grip, 1994). This evaluation includes an empirical evaluation of the forecasts made by all sub-models and the resulting labour market signals provided for students and firms, as well as a survey of the methodology, describing the strong and weak points of the models and possible improvements and extensions.

\subsection{Disequilibrium and Substitution}

A major criticism of the manpower requirements approach refers to the lack of substitution possibilities between the various groups of workers which are distinguished. In traditional manpower forecasting both ex ante and ex post substitution processes are neglected. Fixed coefficients in the models on which the employment forecasts for occupations or types of education are based neglect the effects of technological developments on the occupational structure of employment and the possible upgrading of the skill requirements for particular educational groups. For this reason explanatory variables related to these developments have been introduced in the forecasting models, although trend variables are still very important for modelling shifts in both the occupational and educational structure of employment.

The more fundamental difference of traditional manpower forecasting from neoclassical economic theory refers to the neglect of substitution 
processes which will occur in the adjustment process of the market in case of shifts in labour supply or demand. From the very beginning ROA attempted to incorporate aspects from the labour market flexibility approach in manpower forecasting. De Grip and Heijke (1988) discussed the possibilities of combining information on the potential mobility of workers with a particular educational background to alternative occupations with the traditional point forecasts of future employment. This can be done along two lines. First, labour market flexibility indicators can be used as additional key ratios. Second, labour market flexibility can be integrated fully in the forecasts of the future labour market prospects (cr. Sheldon, 1985). Both lines have been followed. The first line focuses on indicators of potential labour market flexibility, which are presented as "risk indicators' that characterize the more or less structural aspects of the labour market position of the various types of education. These indicators will not be discussed in this chapter, but can be found in Dekker et al. (1994). The second line locuses on the incorporation of the substitution processes that could be expected in case of a gap between ex ante labour supply and demand, in the ex post demand forecasts.

The theoretical framework which underlies ROA's forecasts incorporates in particular these induced substitution processes. This theoretical foundation, which synthesises neoclassical adjustment processes in the framework of manpower forecasting, builds on concepts of both job matching and disequilibrium theory (cf. van Eijs and Heijke, 2000). Borghans and Heijke (1996) developed a model which incorporates the possibility of substitution processes as an adjustment process to an ex ante disequilibrium on the labour market for a particular type of education, which can be applied in manpower forecasting at a relatively low level of aggregation. Following de Grip and Heijke (1988), they distinguished between active and passive substitution. If there is an excess supply of workers with a particular educational background, some of these workers may accepi a job at a lower level. These adjustments are indicated as active substitution. However, this substitution process will mean that there are fewer job openings for the types of education which suffer from this "crowding-out" process. The latter could be characterized as the passive substitution demand. Because the forecasts made indicate the ex ante gaps between supply and demand "the employment obtained through induced adjustments should not be included in labour demand. This implies that only passive substitution is incorporated in the gap indicator.

Figure 7.1 shows the way in which an ex ante supply and demand mismatch for a particular type of education may affect the occupational structure of employment for that type of education (active substitution). Initially, labour supply $\left(S_{i p}\right)$ and demand $\left(D^{A+B}\right)$ are in equilibrium, with 


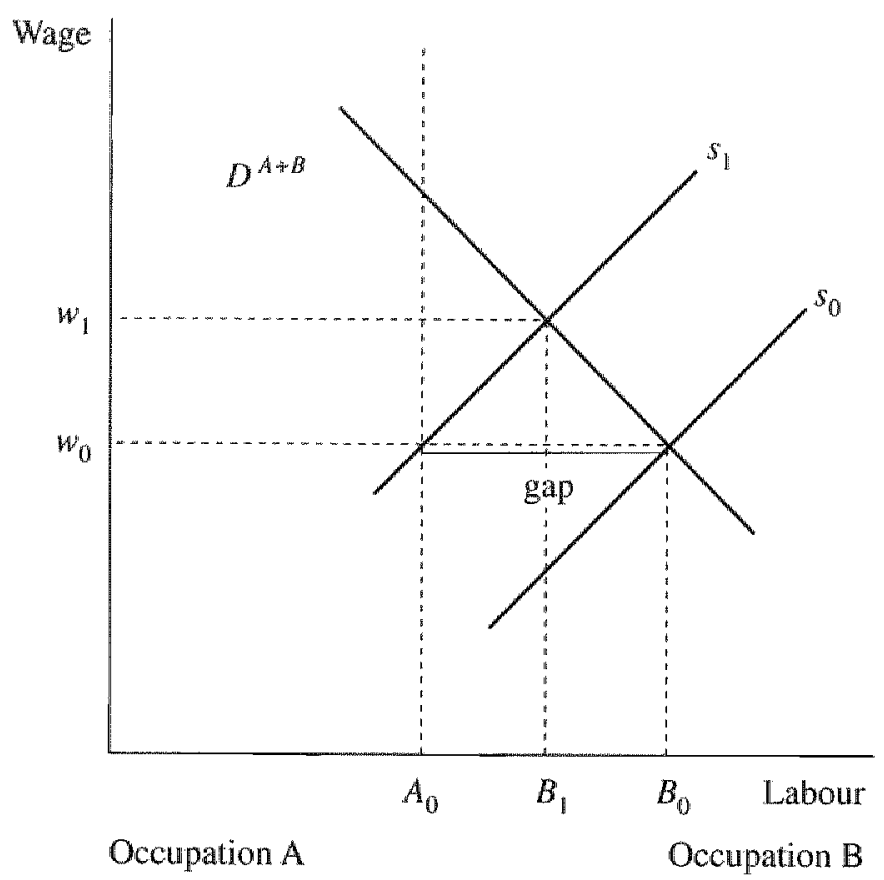

Sounce: de Grip, Borghans and Smits (1998).

Figure 7.1 The effects of an ex ante supply shortage on the occupational structure of employment for a particular type of education (active substitution)

wage level $w_{0}$. At that moment, $A_{0}$ of the workers with this particular educational background are employed in occupation $A$, in which these workers are assumed to be most productive, and $A_{o} B_{o}$ work in occupation $B$. If in the forecasting period labour supply decreases from $S_{o}$ to $S_{l^{\prime \prime}}{ }^{6}$ ex ante forecasits will indicate a demand--supply mismatch at wage level $w_{0}$. However, this gap. which is interpreted as 'good labour market prospects' for the graduates from this type of education, will increase the wage level from $w_{0}$ to $w$. Moreover, most employers who recruited workers with this educational background for occupation $B$ will now no longer recruit these workers. Their wage costs exceed the benefits for the employer, who may start recruiting people with another educational background. This means that at the new equilibrium the majority of the workers are employed in the occupation in which workers with this particular educational background are mosi productive: occupation $A$. Only a minority $\left(A_{o} B_{l}\right)$ will still be employed in occupation $B$. 


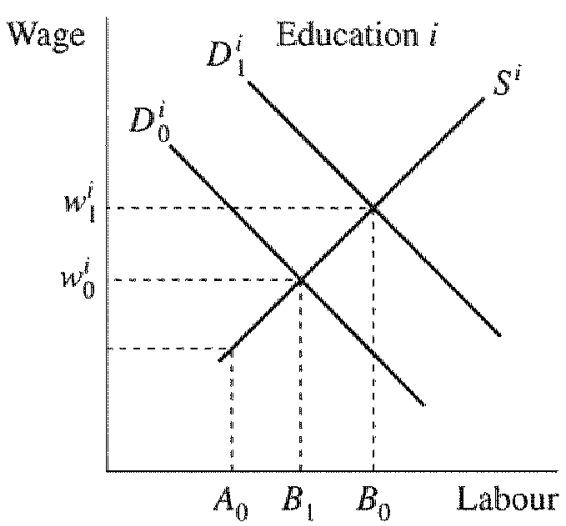

Occupation A Occupation B

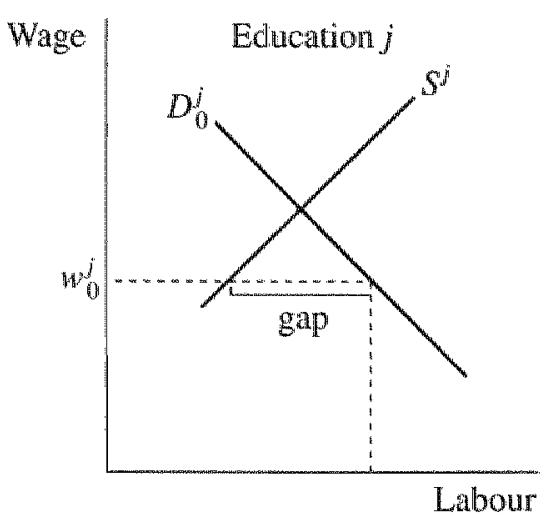

Occupation B

Source: de Grip, Borghans and Smits (1998), silightly adapted.

Figure 7.2 The effects of excess demand for education jon the occupational structure of employment for education $\mathrm{i}$ (passive substitution)

Figure 7.2 illustrates the possible effects of passive substitution processes induced by a demand-supply mismatch for type of education $j$ on the occupational structure of employment for type of education $i$. The left part of the figure relates to type of education $i$, for which supply and demand are in ex ante equilibrium at wage level $w_{0}^{i}$. In this case the majority of the workers $\left(A_{0}\right)$ are employed in occupation $A$ and a minority $\left(A_{o} B_{I}\right)$ in occupation $B$. The right part of the figure relates to type of education $j$. Ex ante forecasts of supply and demand for this type of education indicate excess demand at wage level wh, which is interpreted as 'good labour market prospects" for graduates from this type of education. However, this gap will attract more workers with education $i$ to occupation $B$ jobs $\left(B_{0} B_{j}\right)$, which affects the occupational structure of employment for the latter type of education. The demand curve $D_{\sigma}^{i}$ will shift to the right to $D_{f}^{i}$. Due to this passive substitution effect in occupation $B$, graduates from type of education $i$ will also have good labour market prospects.

\subsection{Occupational and Educational Classification}

A crucial factor for the quality and usefulness of the labour market forecasts is that the occupational and educational classifications used identify the labour market segments as they exist in practice as much as possible. The international occupational and educational classifications used in most 
countries are based on administrative criteria. Administrative occupational and educational groupings are often inappropriate for disaggregated manpower forecasts (Sanderson, 1987). Particularly for a comparison of labour demand and labour supply forecasts by educational category, it is wery important to use an educational classification that takes into account the actual segmentation of the labour market. For types of education which largely operate within the same labour market segment it is incorrect to regard the developments of supply and demand separately, as the substitution between these types of education will be very high in practice. A shortage of the one group will almost automatically lead to an increasing demand for the other group.

In de Grip, Groot and Heijke (1991) a cluster analysis was performed in order to define clusters of occupational groups according to their educational structure. This clustering procedure combines occupations that have very much the same distribution of the total employment in the occupation over types of education. The underlying assumption is that such groups with similar schooling profiles bellong to the same labour market segment and therefore offer opportunities for good forecasts of labour demand by occupational group, because developments will probably be more similar in homogeneous occupational groups.

For educational classification the argument is even stronger, as the comparison of the labour demand and labour supply forecasts is made by type of education. As administrative educational classifications reflect the formal structure of the educational system, they do not indicate the real differences in competencies that people have obtained during their education to fulfil their jobs in the labour market. On the one hand, there are labour market segments with wery strict educational requirements ("craft markets'). Examples are the labour market segments for doctors, lawyers, accountants, and so on. On the other hand, in many segments of the labour market a good deal of educational flexibility can be observed and no oneto-one relationships between education and the labour market exists (de Grip and Heijke, 1988; Sheldon, 1985). These differences should be reflected in the classification.

In the Standaard Beroepenclassificatie '92, Statistics Netherlands builds on the approach developed by de Grip, Groot and Heijke (1991). The various occupational groups distinguished are as homogeneous as possible with respect to the educational requirements in the jobs. Based on this occupational classification - which is compatible with the International Standard Classification of Occupations 1988 (ISCO '88) - ROA's labour market system distinguishes altogether 127 occupational groups at five different job levels ranging from elementary occupations to scientific occupations. 
The educational classification used was developed by Heijke, Matheeuwsen and Willems (2002). The classification is based on the observed substitution possibilities of workers with different educational backgrounds within the same jobs. These substitution possibilities implicitly indicate the overlapping skills of workers who have attended different courses. Borghans (1992) and van der Velden and Borghans (1993) introduced a similarity or competition index, which measures the prevailing substitution possibilities between different educational types.

This similarity index $s$ is defined as:

$$
s_{i, i^{\prime}}=\frac{\sum_{j}\left(\frac{p_{i, j}}{\sum_{j} p_{i, j}}\right)\left(\frac{p_{i^{\prime}, j}}{\sum_{j} p_{i^{\prime}, j}}\right)}{\sqrt{\sum_{j}\left(\frac{p_{i, j}}{\sum_{j} p_{i, j}}\right)^{2} \sum_{j}\left(\frac{p_{i^{i}, j}}{\sum_{j} p_{i^{\prime}, j}}\right)^{2}}}
$$

where: $\begin{aligned} p_{i j}= & \text { the number of people with an education of category } i \text { working in } \\ & \text { occupational category } j ;\end{aligned}$

$s_{i, i^{\prime}}=$ similarity index of educational category $i$ with educational category $i^{\prime}$.

This similarity index $s_{i, i^{\prime}}$ is equal to 0 (no similarity) if both types of education $i$ and $i$ have no overlapping occupations. It is equal to 1 (perfect similarity) if and only if the occupational structure of both educational types is completely equal in the sense that the relative numbers of workers in each occupation is equal for these two educational types. If in total / number of educational types are distinguished, an $I \times I$ matrix $S$ of similarity indexes can be specified. Obviously, the similarity of a type of education with itself $\left(s_{i, i}\right)$ is equal to 1 , and the similarity index is symmetric $\left(s_{i^{\prime}, i}=s_{i^{\prime}, i}\right)$. This implies that one can distinguish $I(I-1) / 2$ similarity indexes. Using the framework provided by Heijke et al. (2002), the new educational classification is obtained by using a cluster analysis to combine educational categories that are very similar to one another. ${ }^{7}$

The starting point of the cluster analysis is the very detailed five-digit classification of the Standactrd Onderwijs Indeling (SOI) of Statistics Netherlands. At this level approximately 800 educational types are distinguished. Based on the substitution possibilities between these educational types within 320 occupational categories, an educational classification is derived in which altogether 113 types of education are distinguished. ${ }^{8}$ 


\section{STRUCTURE OF THE LABOUR MARKET MODEL}

\subsection{General Structure of the Modlel}

Figure 7.3 gives a schematic overview of the labour market forecasting model. ${ }^{9}$ One flow wolume which is important for the demand side of the labour market is the expansion demand, which reflects the movement in employment levels in a particular occupational class or for a particular type of education. The forecasts of expansion slemand are based on the employment level forecasts for economic sectors, which are produced by the CPB Netherlands Bureau for Economic Policy Analysis. Because particular

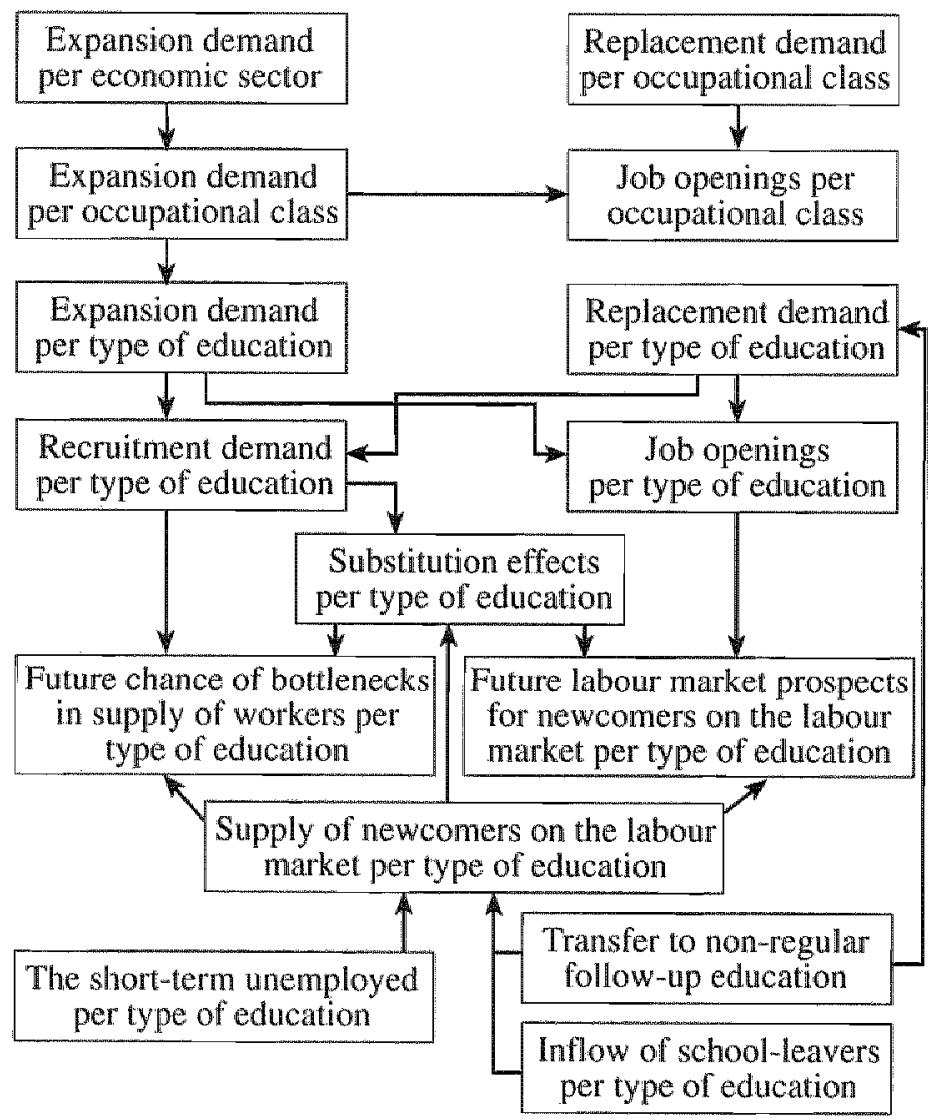

Sonrce: ROA (2001).

Figure 7.3 General structure of ROA's labour market forecasting model 
occupational classes within an economic sector grow more rapidly than others, ROA translates these changes in the economic sectors into the expansion demand per occupational class. Then the implications of the predicted growth in the various occupational classes for the expansion demand for each type of education are determined. An allowance is made at this point for any shifts which may be occurring in the educational structure of occupational classes. The expansion demand per type of education refers to the number of people with a particular educational background that employers would like to be able to employ. The actual change in employment levels per type of education will generally differ from this because changes on the supply side affect relative scarcities and lead to substitution processes.

Demand on the labour market consists not only of expansion demand but also of replacement demand, which arises when workers retire, leave the labour force under an early retirement scheme or because of work disability, withdraw from the labour market temporarily, switch to another occupation, and so on. However, replacement demand only arises if the departure of an employee actually leads to a vacancy for a new entrant. If the departure of a worker is taken as an opportunity to cut employment levels, no replacement demand results. These flows out of the labour market are in fact irrelevant for newcomers.

Thus, only part of the flows leawing the market generate replacement demand. Moreover, there is an important difference between the replacement demand per occupational class and per type of education, because occupational mobility has an influence on the replacement demand per occupational class, but not on the replacement demand per type of education. Switching occupations has no effect on the educational structure of employment. On the other hand, when workers complete part-time studies for a higher level or a different qualification, it means in fact an outflow of workers to another educational category (type of education). In that case a replacement demand does arise in the educational category under which a worker's prewious education was counted.

If employment levels are rising, the expansion demand and replacement demand together comprise the job openings for newcomers to the labour market. If employment levels are declining, job openings can only arise through replacement demand.

To be able to indicate the future labour market prospects for newcomers to the labour market, we have to compare the job openings for newcomers with the expected supply of newcomers. The latter consists of the future flow of school-leavers entering the labour market and the outflow from post-initial training courses during the forecast period, plus the supply of short-term unemployed persons waiting to enter the market at the start of 
this period. It is assumed that the long-term unemployed, who have been looking for work for longer than a year, no longer constitute serious competition for school-leavers.

The forecasts of the flows of school-leavers entering the labour market correspond to the Referentievamingen (Reference Forecasts), which are compiled by the Ministry of Education, Culture and Science for courses in the "regular" (that is full-time initial) education system. ROA disaggregates these forecasts, and supplementary data are used to estimate the effects of the flows from non-regular education on the educational makeup of the flows entering the labour market.

An indication of the future labour market prospects for newcomers to the labour market is derived, for each type of education, by comparing the expected flows of demand and supply with each other. This indicator shows what discrepancy may be expected between the demand and supply for each type of education. But, as mentioned in Section 2.2, excess supply does not imply that the group in question will as a matter of course become unemployed, and a supply shortfall does not automatically mean that there will be unfilled vacancies. In practice, it appears that school-leavers with a type of education for which the supply exceeds demand do suffer from a deterioration of their position, for example, because they are more likely to have to accept work below their level, to receive less favourable contracts, to be less well paid, or to work part-time involuntarily (Wieling and Borghans, 2001). In such a situation, employers would normally modify their demands and recruit people with a higher educational background than was originally contemplated. On the other hand, if there is a supply shortage the position of school-leavers will improve, and they will then not have to accept a job at a lower level, for lower wages, and so forth.

Because of substitution processes, there will be fewer job openings for those with the types of education which suffer from 'crowding out' by types of education with an excess supply. On the other hand, for those with educational backgrounds which are closely related to types of education which are in short supply, there will be extra job openings. These passive substitution effects are thus important determinants of the labour market prospects for types of education.

The comparison of demand and supply also gives an indication of the future risk of labour recruitment problems for each type of education. The expansion and replacement demand jointly determine the recruitment requirement for each type of education. If employment for a particular type of education is declining, this recruitment requirement is calculated in a somewhat different manner than the number of job openings for newcomers to the labour market, because from the employers' point of view it is possible to achieve part of the retrenchment by limiting their recruitment, 
so that fewer of the existing personnel have to be dismissed. Employers will be especially likely to use this option when they face a tight labour market for a particular type of education.

\subsection{Expansion and Substitution Demand}

Figure 7.4 gives an overview of the structure of the ROA expansion demand forecasts. The employment projections by sector of industry, which are based on the Athena model of the CPB Netherlands Bureau for Economic Policy Analysis, are the starting point for the forecasts. The Athena model of the CPB is a multi-sector model of the Dutch economy which distinguishes 14 sectors (CPB, 1990). For each sector a Clay-Clay production function with heterogeneous vintages (annual cohorts) is used. Disequilibrium may arise in the production process and the labour market, which then feeds back into prices, wage rates, investment, the demand for labour, and so on. The employment equation for the industrial sectors is derived from the model for production capacity and consists of three parts: one part describing the vintage effect on labour volume, one part describing

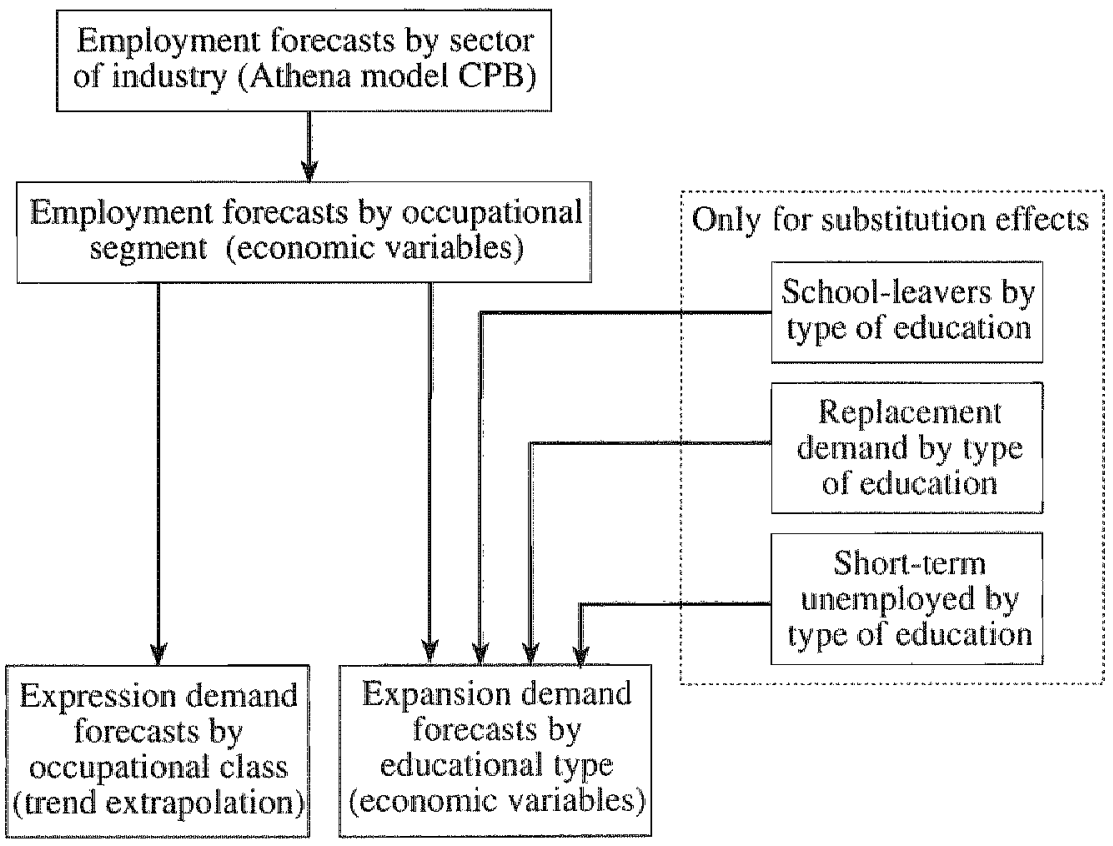

Source: de Grip, Borghans and Willems (1995).

Figure 7.4 Structure of the expansion demand forecasts 
the "disembodied" changes in the number of jobs and one part describing short-term adaptation processes. The employment-level equations for the remaining economic sectors are not derived from a formal production function but were formulated ad hoc on the basis of studies of each sector.

\section{The occupational model}

Starting from the CPB forecasts of employment by sector, a two-step model is estimated to explain the occupational structure of the sectors. The changes in employment levels per economic sector are first translated into employment changes per occupational segment. Then the forecast of expansion demand is further disaggregated by occupational classes. The assumption in the design of the occupational models is that the occupational structure of a sector is entirely determined by the dernand side of the labour market. Changes in the demand per occupational class are determined by shifts in employment between economic sectors and changes in the occupational structure of the employment per economic sector.

Changes in the employment structure are estimated on the basis of the Labour Force Survey data from 1981-99. Because the available time series is rather short, a random coefficients (RC) model has been used. ${ }^{10}$ An RC model gives more reliable parameter estimates without affecting the specificity of the separate occupations. In this RC model each parameter value is a weighted average of the average parameter value over all the pooled occupations on the one hand and estimates for each separate occupation on the other hand. The weighting is determined by the accuracy of the two components. If there is a great deal of variation between the various occupations, a pooled estimate is relatively inaccurate and more weight is placed on the separate estimates. However, if these separate estimates have a high standard error, their weighting is reduced. Thus, an optimal combination is found between the information in the pooled data and in the separate estimates.

There have been changes not only in the estimation techniques, as compared to the approach used in earlier versions of the labour market model (cf. Dekker, de Grip and Heijke, 1990), but also in the specification of the equation. A specification which forecast employment levels has now been replaced with one which forecasts growth. In the earlier method, a regression equation was estimated on the basis of the shares of particular occupations in employment in each economic sector. If, in the most recent year for which observations were available, this share was much larger or smaller than in the previous years, this result was implicitly treated as an anomaly. But by forecasting growth, the implicit assumption is that these unexplained changes in employment levels will continue in the future. However, because an explanatory model of the occupational structure will always be 
insufficient, it is better to treat such anomalous results as an indication of unexplained changes which will continue to have their effects in the future.

For each economic sector, the following specification is taken as a starting point:

$$
\dot{a}^{o s}=\dot{a}^{s}+\beta_{1}^{o s} t+\beta_{2}^{o s} \dot{Y}^{s}+\beta_{3}^{o s} H O \dot{O U R}+\beta_{4}^{o s} U \dot{U R}+\epsilon^{o s}
$$

where:

$\ddot{a}^{\text {os }} \quad=$ the growth rate of occupation $o$ in economic sector $s$;

$\hat{a}^{s} \quad=$ the rate of growth in the total number of people working in economic sector $s$;

$t=$ the number of years between two successive observations. The parameter value of $t$ thus indicates the constant growth rate per year;

$\dot{Y} \quad=$ growth in the capacity of production. In the industrial economic sectors this is determined by calculating how many labour years of labour input would be required if the present physical capacity was fully utilized (that is current employment divided by the utilization ratio $\left(\dot{y}^{*}\right)$ ). For the other sectors this definition is replaced with the gross added value at factor costs (for the construction industry, domestic deliveries excluding imports), $\dot{y}$;

HOUR $=$ the growth in the hours per year worked under employment contracts;

$U R \quad=$ the unemployment rate.

It is assumed that the vector $\beta^{o s}=\left(\beta_{1}^{o s}, \ldots, \beta_{4}^{o s}\right)$ is normally distributed:

$$
\beta^{o s} \sim N\left(0, \Sigma^{s}\right)
$$

Each parameter is thus specific for each occupation $(0)$ in each economic sector ( $s$ ), but because of the random coefficient structure (equation 3.2) there is a reciprocal link between the parameters of the various occupations in the same economic sector. However, not every explanatory variable is used in every economic sector. The explanatory variables correspond to those used in the Athena model of the CPB. Table 7.1 shows which explanatory variables are used for each economic sector. Relative wage costs are not included in the model, for lack of adequate data. Consequently, it is assumed that the wage structure as such does not change, or that the influence of the wage structure on the occupational structure of employment within economic sectors is constant.

The forecasts of expansion demand per occupational segment are 
further disaggregated to forecasts per occupational class. This takes place in a model with a structure similar to that of the model for accupational segments. The difference between the growth of an occuparional class and growth in the occupational segment is estimated, with the constant term as the only explanatory variable for growth. This estimation also employs an RC model.

Table 7.1 Overview of explanatory variables per economic sector

\begin{tabular}{|c|c|c|c|c|c|}
\hline \multirow[b]{2}{*}{ Economic sector } & \multicolumn{5}{|c|}{ Explanatory variables used } \\
\hline & $t$ & $\dot{y}^{\text {in }}$ & $\dot{y}$ & 7hour & $7 \mathrm{er}$ \\
\hline Agriculture, fisheries and forestry & $x$ & & & $x$ & X \\
\hline Food and beverages industry & $x$ & $\mathrm{x}$ & & $x$ & \\
\hline Chemicals & $x$ & $x$ & & $x$ & \\
\hline $\begin{array}{l}\text { Metal, electrical, and transport } \\
\text { requirements industries }\end{array}$ & $\mathrm{x}$ & $x$ & & $\mathrm{x}$ & \\
\hline Other industries & $\mathrm{x}$ & $\mathrm{x}$ & & $\mathrm{x}$ & \\
\hline Energy & $x$ & & & $x$ & \\
\hline Construction & $\mathrm{x}$ & & $x$ & $x$ & \\
\hline Commerce & $\mathrm{x}$ & & $\mathrm{x}$ & & \\
\hline Transport and communication & $x$ & & $x$ & & \\
\hline Banking and insurance & $x$ & & $x$ & $x$ & \\
\hline Other commercial services & $\mathrm{x}$ & & $\mathrm{x}$ & $x$ & \\
\hline Non-commercial services & $\mathrm{x}$ & & $\mathrm{x}$ & $x$ & \\
\hline Government, police, defence and education & $\mathrm{x}$ & & & & \\
\hline
\end{tabular}

\section{The educational demand model}

In earlier versions of the labour market model, the forecasts of the expansion demand per type of education were derived from the occupational forecasts in a way similar to that for the occupational model (cf. Beekman, Dekker, de Grip and Heijke, 1991). The assumption that the demand for labour per occupational segment is independent of supply factors is reasonably plausible, but at the level of types of education allowance must be made for the fact that the actual employment per type of education depends on supply factors.

For instance, in a labour market with high unemployment the competition for jobs may be such that more highly qualified workers displace the less skilled from their 'occupational territory'. The result of this 'crowding out' (cf. Teulings and Koopmanschap, 1989) is that persons with a high level of education occupy jobs previously held by persons with a lower level of education. Consequently, discrepancies arise between the ex ante demand per type of education before the demand has adjusted to the 
supply and the ex post demand for labour, after these adjustments. The ex ante demand is most suitable for ascertaining the tension which may be expected between demand and supply. The adjustments which take place later will in fact be an expression of these tensions between demand and supply. However, it is the ex post demand which is observed in the data. It is important, however, to distinguish this crowding-out effect from the upgrading effect of technological developments and organizational change (see, for instance, Borghans and de Grip, 2000; Bresnahan. Brynjolfsson and Hitt, 2001).

Economists may prefer the classical or neoclassical procedure, by which the phenomenon of displacement is described with the help of the relative scarcity of a certain level of education as expressed in relative wages. However, for lack of adequate information about the wages earned by persons with a given education, it is necessary to resort to an approximation for the influence of wage factors.

By basing the historical demand in the educational model on actual employment levels, any demand and supply factor is incorporated. This would mean that an increase in employment as the result of an increased supply could be interpreted as an increase in the exante demand. This would lead to an underestimation of the tension between demand and supply. To avoid this confusion between demand and supply factors, a model has been developed in which the distinction between the ex ante and ex post demand for labour is explicitly taken into account (cf. Borghans and Heijke, 1996). To enable these two separate categories to be identified, allowance is made in this model for mutual substitution between types of education.

Figure 7.5 shows the construction of the educational model. The ex ante demand per type of education $(e)$ and per occupational segment $(o)$ is determined by the distribution of the types of education in this occupational segment in the most recent year for which observations are available. Because of downward displacement and concentration around the average training level, the ratios between the shares of the various types of education in accupational segment shift as follows:

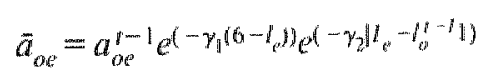

where:

$\bar{a}_{o e}=$ number of people with education $e$ in occupation $o$ according to the adjusted training structure;

$a_{o e}^{t-1}=$ number of people with education $e$ in occupation $o$ in the base year $t-1$;

$l_{e}=$ the level of education $e$ ( 2 for primary education to 6 for academic education); 


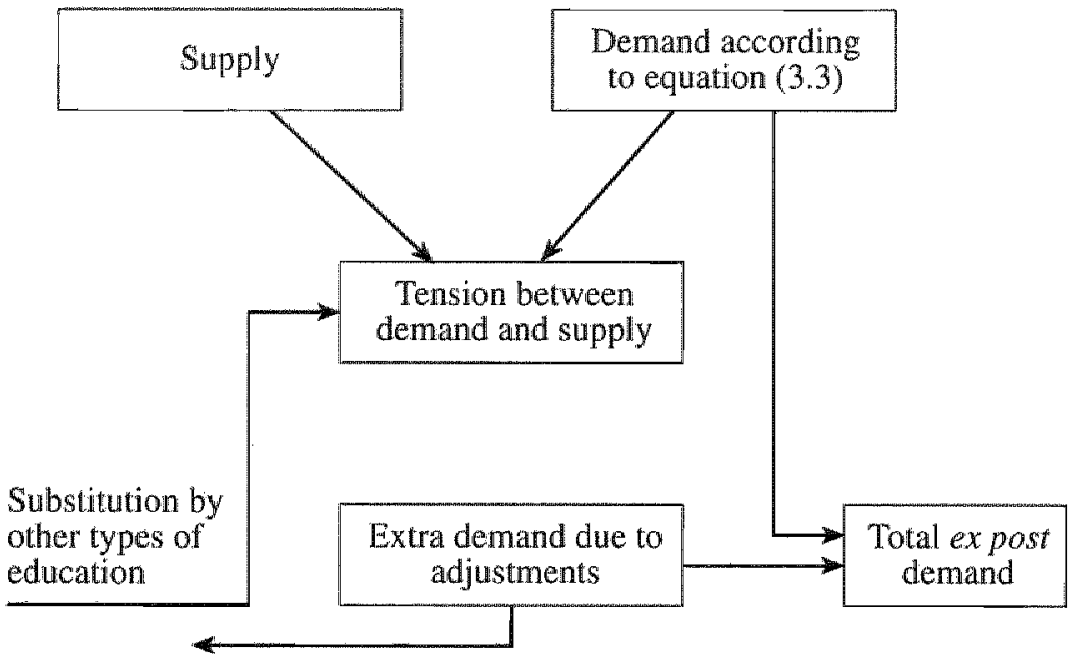

Substitution of other types of education

Source: de Grip, Biorghans and Willems (1995).

Figure 7.5 Components of the demand for labour per type of education

$l_{0}^{j-1}=$ the average level of the types of education in occupation o in the base year $t-1$;

$\gamma_{1}=$ coefficient indicating the extent of downward displacement in a five-year period;

$\gamma_{2}=$ coefficient indicating the average degree of concentration for a five-year period.

If the supply of a type of education is greater than the demand, the labour market position of that type of education will, according to this model, deteriorate. As a result, newcomers on the labour market will have to switch to other jobs and accept less attractive jobs. However, the opposite also holds. If the supply of a type of education is lower than demand, workers with other educational backgrounds will be pulled to these jobs. This will increase the demand for the latter educational categories.

The assumption is that both in the 'push' and the 'pull' case the degree of switching to other jobs for a type of education is proportional to the job structure of this type of education in the previous period. By reiterating this substitution process a number of times an equilibrium situation is found, indicating the ex ante demand with substitution.

This expansion demand with substitution indicates how great the 
demand for school-leavers with a given educational background is, if no allowance is made for the extent to which people with this type of education adjust to the labour market situation, but allowance is made for the increase or decrease in demand as a result of supply-demand discrepancies by other types of education. The reason for this is that adjustments made by people with a particular type of education would in themselves already indicate a worsening in their situation (at least, in the event of an excess of supply). If the post-adjustment employment level ss subtracted from the excessive supply, these worsened prospects would be underestmated. But the reduction in employment opportunities as a result of adjustments made by people with other types of education does mean that employment possibilities are worse, so this component nust be incorporated in the ex ante demand.

ROA's forecasting model distinguishes the vanous processes which determine future employment for particular types of education. First, changes in labour demand in an economic sector affect employment for the skill categories employed in that sector. In addition to this industry effect, there will also be different changes in the employment levels for the various occupational classes within a single economic sector. This occupotional effect is due to some extent to the heterogeneity of the economic sectors as these are defined, but also to changes in the activities within an economic sector. Moreover, the skills which are demanded in these occupations also change due to technological and organizational developments (ce. Bresnahan et al., 2001). Because of these changes, some types of edtcation which are better adapted to the developments in the demand for qualifications will show a positive education effect. These three effects combined represent the total expansion demand for a particular type of education. As a result of discrepancies between labour demand " and supply there are, inevitably, additional shifts in dernand as employers adjust their desires in accordance with the availability of workers. The latter effect is designated the substitution effect. As described above we can differentiate here between active substitution, resulting from supply-demand mismatches for the type of education concerned, and passive substitution, which is due to spillower effects from supply-demand mismatches for other types of education.

The model structure distinguishes between the "demand-led" changes in skill requirements on the one hand and the substitution or "crowding-out" effects relating to labour market mismatches on the other hand. The first three effects indicate the 'demand-led' changes in the skill requirements due to shifts in the industry structure, the occupational structure and the skills required in the various occupations, respectively. The latter two effects indicate the substitution processes due to labour market mismatches. 


\subsection{Replacement Demand}

Replacement demand is an important component of the future demand for newcomers on the labour market (cf. de Grip, Meijboom and Willems, 1994). It can be the result of permanent departures from the labour force due to retirement and early retirement as well as temporary withdrawals such as married women stopping work because of childbirth and childrearing. Replacement demand for a particular occupational category can also be due to occupational mobility. As in the previous section, we describe the methodology used, first in the forecasts of replacement demand by occupational class and then by type of education.

\section{Occupational classes}

Figure 7.6 is an input-output table for the entire population, in which these mobility processes are schematically reproduced at an aggregated level (see also Willems and de Grip, 1993). The inner part of the input-output table contains the mobility flows within the labour market. Some of these flows are indicated by the capital letters $A$ to $G$. Flow $A$ indicates the number of employees who continued to work in occupation $l$ during the period $(t-n, t)$. Flows $B$ and $E$ represent job-to-job mobility. Flows $C$ and $D$ represent departures from employment, to unemployment and non-availability,

\begin{tabular}{|c|c|c|c|c|c|c|}
\hline $\mathrm{C}_{r-n}$ & Occupation 1 & Occupation l & Unemployed & $\begin{array}{c}\text { Outside } \\
\text { labour force }\end{array}$ & $\begin{array}{l}\text { Outflow } \\
\text { population }\end{array}$ & Total \\
\hline Decupation 1 & A & B & $\mathrm{C}$ & $\mathrm{D}$ & & $W_{1 t-n}$ \\
\hline Occupation 1 & $E$ & & & & & $W_{t r-n}$ \\
\hline Unemployed & $F$ & & & & & \\
\hline $\begin{array}{l}\text { Outside } \\
\text { labour lorce }\end{array}$ & $\mathrm{G}$ & & & & & \\
\hline \multicolumn{6}{|l|}{$\begin{array}{l}\text { Inflow } \\
\text { population }\end{array}$} & \\
\hline Total & $W_{1 t}$ & $W_{l s}$ & & & & \\
\hline
\end{tabular}

Source: Willems and de Grip (1993).

Figure 7.6 Input-output table of labour market flows 
respectively. The latter indicates changes such as retirement and voluntary exit, particularly of married women. The unemployed who have found a job during the period $(t-n, t)$ are indicated by the letter $F$. Finally, fow $\mathrm{G}$ refers to new positions gained by those who were not awailable for the labour market at time $t-n$, such as school-leawers who find a job and women who re-enter the labour market.

The replacement demand should be defined in relation to expansion demand. Where there is an increase in employment, the replacement demand is equal to the number of workers who leave a certain job during the period $(t-n, t)$. The vacancies that thus appear will have to be filled before there can be a rise in the total numbers employed. If there is a decrease in employment, not all of the vacancies created by departing employees will be filled. The replacement demand is then not equal to the total number of departures from a certain job, but rather to the number of vacancies that are actually refilled, that is, the total inflow of labour to the job in question. The concept of replacement demand can be explained further using Figure 7.6. If there is an increase in employment, the replacement demand for occupation $I$ is equal to the sum of the flows $B$, $C$ and $D$ (the total outflow). However, if employment in occupation $l$ decreases, the sum of flows $E, F$ and $G$ (the total inflow) gives the replacement demand.

The first step in modelling future replacement demand per occupational class is a description of the inflow and outllow patterns by occupational class in a historical period. Because there is no appropriate data for mobility flows on the labour market, stock data are used. By means of the so-called cohort components method we calculate cohort change rates based on the number of persons of the same birth cohort who were employed at two different times (cf. Shryock and Siegel, 1980). These cohort change rates can be rewritten as average annual net inflow or outflow percentages. ${ }^{12}$

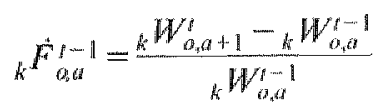

where:

${ }_{k} \dot{F}_{a, a}^{t-1}=$ the annual net inflow or outflow ratio of workers in occupational class of age group a (with class-width $k$ ) at time $r-1$ during the period $(t-1, t)$

${ }_{k} W_{o, a}^{t}=$ the number of people working in occupational class o of age group $a$ (with class-width $k$ ) at time $t$ :

If $F^{t-1}<0$ there is a net outflow for a certain age group from an occupational class, and if $F^{r-1}>0$ there is a net inflow. 
The second step in modelling is to translate these inflow and outflow percentages into the replacement demand by occupational class. As stated above, for occupational classes with an increase in employment in the period $(r-1, v)$, replacement demand is equal to total net outflow in this period. However, for occupational classes which faced a decrease in employment, not all vacancies due to the outflow of workers will have been filled. Therefore, replacement demand for these occupational classes equals the number of vacancies that were actually refilled, that is, the total inflow of workers in the occupational class. In this way the more or less 'structural" replacement demand is derived.

This methodology measures only the net flow to or from an occupational class. This means that replacement demand satisfied by re-entering workers of the same age cohort is not measured. Hence, replacement demand is actually measured for newcomers on the labour market. However, this is exactly what is intended, inasmuch as ROA's forecasting model focuses on the prospects for newcomers on the labour market.

An RC model is then estimated in which the net inflow or outflow ratios are explained on the basis of the average inflow or outflow from the total working population on the one hand and the occupation-specific deviations per age and sex group on the other. This approach guarantees that the sum of the net flows among the occupations corresponds to the total inflow or outflow.

Written mathematically:

$$
\vec{F}_{0}=\dot{F}+\Sigma_{x} \beta_{o x} D_{x}
$$

where:

$F_{0}=$ vector of net inflow of outflow ratios for occupation $a$, with observations per sex, age group and year;

$F=$ the same, but then for the total working population;

$D_{x}=$ matrix with dummy variables; elements are equal to 1 for cohort $x$ and 0 elsewhere;

$\beta_{o x}=$ random parameters.

The third step is to project the historically measured net replacement demand rates per age and sex group for a particular occupational class onto the age and sex structure of the workers at the beginning of the forecasting period. Moreover, the historically observed cohort change rates are corrected for business cycle effects and for expected changes in participation rates. 13

The business cycle correction is equal to the difference between the 
change in the total number of working persons and the change in the labour force in the historical period. This correction offsets the outflow of workers who become unemployed because of cyclical fluctuations in employment levels. The correction for changes in the participation rate is the difference between the growth in the labour force in the historical and the forecasting period. Both correction factors are sex-and age-specific. If the cyclical correction and the participation rate correction are combined, the forecast future outflow ratio by age category will be:

$$
\begin{aligned}
& { }_{k} \dot{W}_{a, a}^{m, m}={ }_{k} \dot{W}_{a, a}^{i n}+{ }_{k} L F_{a}^{t, n}-{ }_{k} W P_{a}^{t_{a} n}+{ }_{k} L F_{a}^{u, m}-{ }_{k} L F_{a}^{t, n} \\
& ={ }_{k} \dot{W}_{a, a}^{n-{ }_{k}} W P_{a}^{t, n}+{ }_{k} L F_{a}^{b m}
\end{aligned}
$$

where:

${ }_{k} \dot{W}_{o, a}^{t, m}=$ the expected average annual net inflow or outflow ratio of workers in occupational class o of age group a (with classwidth $k$ ) at time $t$ during the forecasi period $(t, t+m)$;

${ }_{k} L F_{a}^{t n}=$ the average annual growth ratio of the total labour force of age group $a$ (with class-width $k$ ) at time $t-n$ during the period $(t-n, t)$

${ }_{k} L F_{a}^{t, m}=$ the expected average annual growth ratio of the total labour force of age group $a$ (with class-width $k$ ) at time $t$ during the forecast period $(t, t+m)$;

${ }_{k} W P_{a}^{t, n}=$ the average annual rate of growth of the total number of working persons of age group $a$ (with class-width $k$ ) at time $t-n$ during the period $(t-n, t)$.

Future replacement demand is further determined in the same way as historical replacement demand. That means that for occupational classes with an expected increase in employment, replacement demand equals net outflow. For occupational classes for which a decrease in employment is expected, replacement demand is equal to the total net inflow.

\section{Types of education}

Replacement demand by type of education must be interpreted differently from replacement demand by occupational class, as net mobility between occupational classes must also be taken into account in the latter. However, when a worker with a certain educational background changes occupation, this does not create a vacancy for a newcomer on the labour market with the same educational background. Therefore, this does not influence replacement demand for newcomers for the type of education in question. 
On the other hand, when workers complete training courses at a higher level of education or different type of education at the same level, there is replacement demand in their previous type of education.

Moreover, there is another difference between replacement demand by occupational class and by type of education. If someone leaves a certain occupational class and is replaced by an employee with another (for example, higher) educational background, there is a replacement demand for the occupational class in question. When such displacement or substitution effects occur, however, there is no question of replacement demand for the type of education in question. Rather, there is an employment decrease for one type of education and an employment increase for the other. However, this relation between expansion demand and replacement demand is only implicitly taken into account in the expansion demand forecasts. Moreover, one could ask whether the replacement demand model should incorporate the forecast negative expansion demand, instead of the historical development of employment.

In compiling the forecasts for the period 2001-2006, it was possible to use data differentiated by sex and age category for the number of workers per occupational class, and per type of education, for the years 1987-1999 and 1992-1999, respectively. On the basis of the data, the cohort change rates were determined. By applying an RC model, which incorporates the total labour market outflow, one obtains the expected net labour turnover coefficients for the forecast period, on the basis of which the replacement demand can be determined.

\subsection{Forecasts of Inflow of School-leavers}

For each type of education, forecasts have been made of the potential flow of school-leavers into the labour market. Several data sources thave been used for these forecasts. The Ministry of Education and Science makes annual forecasts of the number of school-leavers from full.time and parttime education. These so-called reference forecasts are differentiated by sex and age, but they are at a higher level of aggregation than ROA's categorization of types of education (Ministerie van Onderwijs, 2000).

The forecasting model used is based on a transition matrix based on the composition of full-time education and a classification of the population by level of education. Flow coefficients relate the 'origin' of students in year $r$ to the "destination' of these students in year $t+1$. By means of these flow coefficients, future numbers of students from each educational category can, step by step, be forecast. However, such a straightforward approach would suppose that students" choices remain unchanged during the entire forecasting period. Therefore, the flow coefficients of students who obtain 
a certain qualification are considered strategic flow coefficients. These strategic flow coefficients are the dynamic elements of the model, as they are determined by (modified) trend extrapolations.

As the ministry's forecasts of school-leavers are at a higher level of aggregation with regard to the types of education, distribution keys are needed to break down these forecasts. These distribution keys are formulated from various additional data sources.

Besides those leaving school with a qualification, the reference forecasts cover students who end their studies without a diploma. With the help of education matrices for 1995 and 1998, these school-leavers can be reassigned to any preliminary course from which they had obtained a diploma.

A forecast is also made of the flow from post-initial education into the labour market. This flow indicates the effects of lifelong learning on the educational structure of the labour supply. Data about the inflow of "newcomers' in the labour market from posi-initial education are derived from the Educational Accounts of Statistics Netherlands, which builds on the underlying data from the Labour Force Survey. Because of data limitations, we simply assume that in the forecasting period the proportion of workers with a particular educational background that will complete a post-initial training course giving them another educational background is the same as in the year 1997, for which we have data on the participation in post-initial training.

\subsection{Labour Market Gap Indicator}

By matching labour demand with labour supply, an indicator of the future labour market situation (IFLM) can be constructed. This indicator of labour market prospects is constructed for each of the types of education which are distinguished. As explained above, labour demand is the sum of the (positive) expansion demand, replacement demand and the passive substitution demand due to excess demand or supply for closely related lypes of education. Labour supply consists on the one hand of the expected. inflow in the period 2001-2006 and on the other hand of the number of unemployed with the same educational background who had been unemployed for less than one year in 2001. The exclusion of those who were unemployed for more than one year is based on the supposition that they do not compete on the labour market with school-leavers with the same type of education.

The formula for the indicator for a specific type of education is as follows:

$$
I F L M_{e}=\frac{E_{e 01}+I N S_{e 01-06}+U_{e 02}}{E_{e 01 .}+\max \left(0, E D_{e 01-05}\right)+R D_{e 01-06}+S D_{e 01-06}}
$$


where:

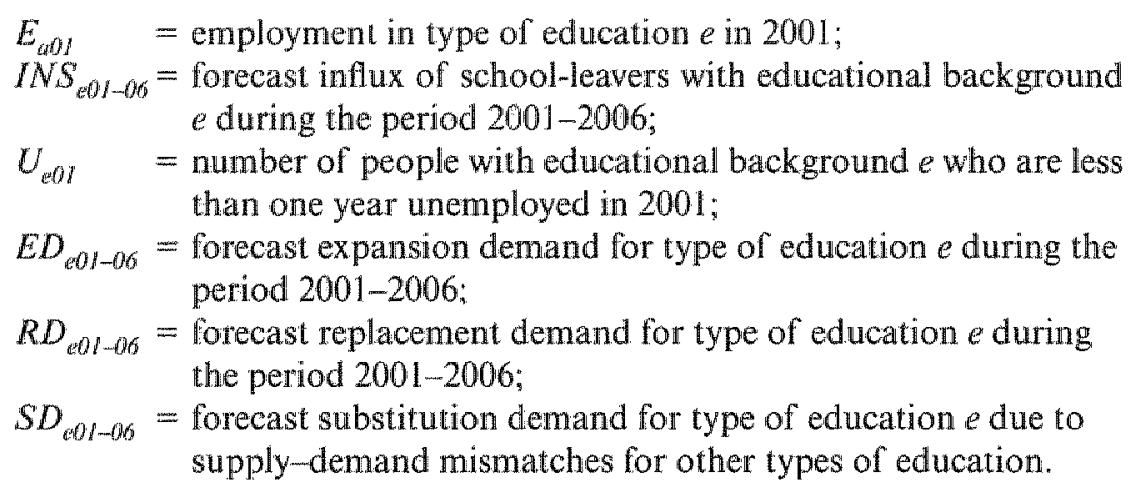

The indicator of the future labour market situation is translated into a qualitative characterization of the expected labour market prospects on a fivepoint scale: very good, good, reasonable, moderate and poor prospects. Such a qualitative characterization in quite broad terms suffices for various purposes, including vocational and educational guidance counselling. Moreover, it prevents too much significance being attached to the exact numbers produced by the equation, which also increases the reliability of the forecasts.

\section{EMPLOYMENT FORECASTS BY EDUCATIONAL LEVELS UP TO 2006}

In this section the employment forecasts for the Netherlands are presented; they were produced recently through the use of ROA's labour market forecasting model. The forecasting period is for 2001-2006. The original forecast is broken down into 13 economic sectors, 127 occupational groups and 104 types of education. In this section, only figures on educational levels diflerentiated by broad education categories are presented.

Whereas the growth in overall employment in the Netherlands is mainly determined by the international economic situation, the shifts in composition of employment according to economic sector, occupation and education seem to be predominantly structural in character, with two important trends playing a role. On the one hand, the Dutch economy is increasingly developing into a services economy: both the markets and employment are subject to what is called a 'tertiarization' of the economy. This trend is reinforced by the fact that the increase in productivity in the services sector is lagging behind that in industry. ${ }^{14}$ Moreover, industrial firms increasingly focus on their core activities, which results in certain activities (cleaning, 
catering, and the like) being outsourced to specialized companies in the commercial service industry. On the other hand, a knowledge economy is developing, which results in the 'upgrading' of the level of education required in virtually all economic sectors.

The developments in employment of the various education categories, as presented in Table 7.2 , show the cumulation of the two trends mentioned. The tertiarization is again reinforced by the limited growth in productivity in the services sector and the outsourcing of tasks not belonging to the core activities of ind ustrial firms to the commercial service industry. Finally, the upgrading process of the occupational structure in the warious sectors is reinforced by the increase in qualification requirements in many occupational groups. As a result of the interaction between these developments the Netherlands can increasingly be characterized as a knowledge-intensive services economy.

Table 7.2 Expansion demand according to education category, in number and as a percentage of employment, the Netherlands, 2001-2006

\begin{tabular}{lrc}
\hline Education category & Number & Average annual \% \\
\hline Primary education & -121500 & -5.2 \\
PVE theory & 5000 & 0.2 \\
PVE agriculture and technology & -58000 & -2.5 \\
PVE economics & -11500 & -1.2 \\
PVE nursing & -1000 & -1.7 \\
HGSE & 59000 & 3.0 \\
IVE agriculture and technology & 109500 & 2.0 \\
IVE economics & 63500 & 1.5 \\
IVE service industry and health care & 52500 & 1.4 \\
HVE agriculture and technology & 33000 & 2.2 \\
HVE economics & 58500 & 3.5 \\
HVE teacher training and social studies & 50500 & 1.8 \\
HVE paramedical & 29500 & 4.1 \\
UE agriculture and technology & 19500 & 2.6 \\
UE economics & 55500 & 5.1 \\
UE languages and social studies & 37000 & 3.9 \\
UE nedical & 1000 & 0.3 \\
Total (incl. education unknown) & 425000 & 1.2 \\
\hline
\end{tabular}

Notes: PVE $=$ Preparatory Vocational Education

HGSE = Higher General Secondary Education (including Pre-university education) IVE = Intermediate Vocational Education (including apprenticeships) HVE $=$ Higher Vocational Education $\mathrm{UE}=$ University Education

Source: ROA. 
The highest expansion demand for the period 2001-2006 is expected to take place in UE economics, whereas the largest decrease in employment is predicted for those who have had primary education only. The expansion demand for UE agriculture and technology and UE medical will fall behind the demand for employees with an economic background. This means that the trend for the period 1996-2000 is continuing, when employment for UE economics increased by 7.7 per cent per annum and for UE agriculture and technology by 5.4 per cent, al though the overall rate of employment growth will be lower over the coming years. All lower education categories are expected to suffer a negative expansion demand, with the exception of PVE theory. This represents a deterioration in comparison with the previous years. At IVE level, employment is expected to remain on the increase, and in particular IVE agriculture and technology is expected to grow to considerably higher levels than in the past years. At HVE level, HVE economics and HVE paramedical will continue to grow more vigorously over the next years than HVE agriculture and technology and HVE teacher training and social studies. Within the education categories considerable differences may still occur. Within UE agriculture and technology, for instance, the expansion demand for UE agriculture and environmental sciences is 2.4 per cent; for UE information science and management computer science it is 8.7 per cent.

Table 7.3 giwes an overview of the various components of the expected development in employment according to level of education. ${ }^{15}$ Distinctions are made between:

1. differences in the development in employment within economic sectors, the economic sector effect:

2. shifts in the occupational structure within economic sectors, the occupational effect;

3. changes in required educational background within occupations, the educational effect. This effect reflects the degree of upgrading within occupations;

4. additional demand (in a positive or negative sense) caused by shortages or excesses in supply of types of education that are related from the point of view of the labour market, the passive substitution effect. This effect reflects how courses of education of a higher level with excess supply crowd out other courses of education, or, conversely, how a lack of supply attracts people with a related educational background.

The table shows that the differences in the increase in employment between economic sectors have an effect on the shifts in employment structure according to level of education. There is a slight increase of this effect 
Table 7.3 Components of the development in demand by level of education (net effects*), the Netherlands. 2001-2006**

\begin{tabular}{|c|c|c|c|c|c|}
\hline Level of education & $\begin{array}{l}\text { Economic } \\
\text { sector } \\
\text { eflect } \%\end{array}$ & $\begin{array}{l}\text { Occupational } \\
\text { efrect } \%\end{array}$ & $\begin{array}{c}\text { Educational } \\
\text { ellect } \%\end{array}$ & $\begin{array}{c}\text { Passive } \\
\text { substitution } \\
\text { a }\end{array}$ & Total \% \\
\hline Primary education & 5.7 & -3.2 & -25.2 & -3.9 & -26.5 \\
\hline PVE & 5.9 & -3.8 & -7.8 & -5.7 & -11.5 \\
\hline HGSE, IVE & 6.0 & -0.2 & 4.11 & -1.3 & 8.6 \\
\hline HVE & 6.4 & 2.3 & 5.3 & 4.2 & 18.3 \\
\hline UE & 6.9 & 7.0 & 4.5 & 9.8 & 28.3 \\
\hline Tolal & $6 . \mathbb{1}$ & 0.0 & 0.0 & 0.0 & 6.1 \\
\hline
\end{tabular}

Noves: PVE = Preparatory Vocational Education

LGSE = Lower General Secondary Education

IVE = Intermediate Vocational Education (including apprenticeships)

HGSE = Higher General Secondary Education (including Pre-university Education)

HVE $=$ Higher Vocational Education

$\mathrm{UE}=$ Uniwersity Education

* The percentages in this table relate to the entire period $2001-6$.

* The totals of the occupational effect, the educationat effect and the substitution

effect are zero in every case, because these figures refer to shifts in employment shares. Thus, a positive occupational efrect at one educational level necessarily implies a megative effect at another level.

Source: ROA.

with the level of education, from primary education by 5.7 per cent to UE by 6.9 per cent. This indicates that the knowledge-intensive sectors, in which the knowledge intensity is approached through the employment structure by level of education, are on average growing more rapidly than the less knowledge-intensive sectors. The changes in inter-sectorial employment structure indicate that we are moving towards a knowledge economy.

Yet considerable differences between levels of education only begin to show under occupational effect. Due to the intra-sectorial shifts in occupational structure the demand for workers educated to intermediate level is decreasing. whereas the demand for people with higher education (HVE and UE) is increasing. These occupational effects are once again increased through changes in required educational background within occupations: for primary education in particular there is a markedly negative educational effect of no less than -25.2 per cent, and PVE is also expected to have a large negative educational effect of -7.8 per cent. As for people with higher education, the positive occupational effects are reinforced by positive educational effects, causing employment in the period 2001-2006 to increase by 5.3 per cent for HVE and by 4.5 per cent for UE. The intermediate level is 
an exception to this pattern: here, a positive educational effect of 4.1 per cent compensates a small negative occupational effect of -0.2 per cent. In general, the growth of the intra-sectorial employment structure is another indication of the development of the knowledge economy. The expected increase in employment for accupations is higher if the average level of education for these occupations is higher, whereas, in addition, the average level of education within the occupations is increasing.

Finally, the inter-sectorial and intra-sectorial shifts in employment are reinforced by the substitution demand. The table shows that the substitution effect for the period 2001-2006 goes in the same direction as the occupational effect and the educational effect at all levels of education, with the exception of the educational effect for HGSE and IVE. For those with higher education at the UE level in particular, the substitution effect is very substantial. This substitution effect results from the large shortages in supply that apply to many types of education within higher education. This gives rise to extra substitution demand for related courses in higher educa* tion. The effect is a kind of unchecked spread, which causes the problem areas on the labour market to spread over virtually all types of courses in higher education.

\section{STUDENTS' LABOUR MARKET PROSPECTS UP TO 2006}

As Figure 7.5 shows, it is possible to give an indication of the expected labour market prospects for newcomers to the labour market, differentiated by education category, on the basis of the predicted changes in demand and supply on the labour market. The conclusions on this point are based on the Indicator of Future Labour Market prospects (IFLM) for each education category, which reflects the relationship between the supply of labour with that educational background and the corresponding demand (see equation 3.7). If the supply of labour is smaller than the demand, and the IFLM is thus less than 1.00 , the labour market is characterized as good. If the value of the LFLM is even below 0.85 , this is characterized as very good labour market prospects. On the other hand, if the IFLM lies between 1.00 and 1.05 , so that the excess supply is not much greater than the level attributable to labour market friction, this is characterized as reasonable labour market prospects. For higher values of the IFLM, the labour market prospects for that education category are characterized as moderate, or, if the IFLM exceeds 1.15, as poor.

The developments in supply and demand in the Netherlands are reflected at the aggregation level of 17 education categories, which comprise 104 
types of education. It should be noted that the labour market prospect of a type of education may show a marked difference from the prospect of the education category it belongs to.

The future labour market prospects, as presented in Table 7.4, appear to be reasonable for those school-leavers whose highest completed education is primary education (to a large extent dropouts from PVE). It is remarkable that those school-leavers who may be considered untrained have reasonable labour market prospects, particularly in view of the generally moderate or even poor prospects of school-leavers from PVE. This may be explained through the high replacement demand for primary education as a result of workers with this eclucational background finishing further education at a later date. The effect of this continuous learning is much more

Table 7.4 Indicator of future labour market prospects (IFLM) of schoolleavers and graduates, the Netherlands, 2001-2006

\begin{tabular}{lcl}
\hline Education category & IFLM & $\begin{array}{c}\text { Characterization of } \\
\text { labour market prospects }\end{array}$ \\
\hline Primary education & 1.01 & reasonable \\
PVE theory & 1.07 & moderate \\
PVE agriculture and technology & 1.11 & moderate \\
PVE economics & 1.18 & poor \\
PVE nursing & 1.11 & moderate \\
HGSE & $1 . \| 1$ & moderate \\
IVE agriculture and technology & 0.99 & good \\
IVE economics & 0.98 & good \\
TVE service industry and health care & 1.00 & good \\
HVE agriculture and technology & 0.89 & good \\
HVE economics & 0.96 & good \\
HVE teacher training and social studies & 0.90 & good \\
HVE paramedical & 0.88 & good \\
UE agriculture and technology & 0.85 & very good \\
UE economics & 0.82 & very good \\
UE languages and social studies & 0.87 & good \\
UE medical & 0.97 & good
\end{tabular}

Notes: PVE = Preparatory Vocational Education

IVE = Intermediate Vocational Education (including apprenticeshipss)

HGSE = Higher General Secondary Education (including Pre-university

Education)

LGSE = Lower General Secondary Education

HVE = Higher Vocational Ed ucation

UE = Uniwersily Education

Sounce: ROA. 
limited for the four education categories at PVE level. This causes the replacement demand to be less high for this category than for primary education, and it causes the future labour market prospects to be correspondingly worse for school-leavers from PVE. In addition, the poor labour market prospects for PVE economics stand out even more unfavourably as a result of the very high influx of school-leavers with this educational background into the labour market.

At the level of HGSE/VE, it is striking that school-leavers from general HGSE education have moderate prospects, whereas school-leavers from the three different IVE education categories generally enjoy good prospects. This difference between HGSE and IVE is to a large extent attributable to the expected very high influx of school-leavers from HGSE into the labour market. This influx amply exceeds the similarly high expansion demand and replacement demand for these school-leavers. As for IVE agriculture and technology, IVE economics, and IVE service industry and health care, the influx is slightly lower and the expansion demand and replacement demand are slightly higher than the national average. As a result the problems employers experience with recruitment of IVE personnel are in general substantial, whereas there are virtually no problems with recruitment of staff with generall education at the HGSE level.

Similar to IVE, the labour market prospects are expected to be favourable for graduates from all education categories of HVE and LE. An important reason for this is that employment for these education categories is expected to show higher than average growth, with the exception of UE medical, whereas the increase in influx, with the exception of HVE economics and UE economics, will clearly fall behind the average national growth. Although there is also a less than average replacement demand for all education categories of HVE and UE, except for HVE teacher training and social studies, this will nevertheless on balance result in good prospects for higher education graduates. Employers will therefore continue to be confronted with substantial problem areas on the labour market when recruiting higher educated staff. Due to a low influx of UE agriculture and technology into the labour market and a very high expansion demand for UE economics, these two education categories are even expected to offer very good labour market prospects to graduates and to prove very substantial problem areas with regard to the supply of personnel. Incidentally, both the limited expansion demand and the low influx for UE medical into the labour market are remarkable. The problems with the supply of highly educated medical personnel can, however, become even more substantial if the influx of graduates from medical education into the labour market does not keep pace with a possible increase in expansion demand caused by extra funding for the social service sector. 
The general picture of the future prospects of school-leavers and graduates in the Netherlands is that the division on the labour market will remain: graduates from IVE, HVE or UE may generally count on good prospects, whereas the prospects for school-leavers from PVE or HGSE are considerably less favourable.

\section{CONCLUSIONS}

This chapter has discussed the labour market forecasting model developed by ROA, which goes several steps beyond the scope of the traditional manpower requirements approach. In this chapter we have dealt in particular with the objectives, the basic principles and the structure of the model. To illustrate the capacity of the forecasting model, we have presented the employment forecasts by category of education and the students" labour market prospects for the period 2001-2006.

The steps taken by ROA to transcend the traditional manpower requirements approach can be summarized as follows:

1. a change from a planning tool to a transparency approach;

2. an improved theoretical foundation;

3. improved data input;

4. the use of occupational and educational classifications, which distinguishes homogeneous groups of workers;

5. the use of more sophisticated econometric models.

Although progress has been made on several points and the methodology which has been developed consists of a logically designed structure of procedures and models, further improvements in both the quality and the utility of the information generated by ROA's labour market forecasting model will remain an important goal. These further improvements include:

1. to increase the explanatory power of the forecasting models, particularly of expansion demand and the inflow of newcomers on the labour market. Thus far, the forecasting model for the inllow of newcomers lacks any explanatory variables. A first step in the development of an explanatory model would probably be the introduction of a "discouraged workers effect' with respect to the choice between further full-time education and labour market entrance. The educational model of expansion demand should be more explicitly based on the theoretical foundations developed with respect to the distances between the various types of education in relation to the comparative advantages of the various educational backgrounds 
of workers and the adjustment processes facilitated by the additional training of workers with an educational background that does not perfectly match the skill requirements in the occupation concerned (cf. van Eijs and Heijke, 2000);

2. to improve the consistency between the models for expansion and replacement demand for types of education which face declining employment lewels.

Moreover, we intend to develop the sectorial approach of the information system further in the coming years, and to put more emphasis on questions of recruitment problems and the (re)training of unemployed and employed workers in relation to the recruitment problems expected in the various labour market segments. The usefulness of the labour market information for the human resource management of firms will also be increased by incorporating the expected adjustment processes of firms in case of a gap between $e x$ ante supply and demand, estimated in a way similar to that in Wieling and Borghans (2001), with respect to the adjustment processes from the point of view of the actors on the supply side of the labour market.

Attention will also be paid to the regionalization of the labour market information broken down by economic sector, occupation and education. A major step in this direction has been made in the Regional Labour Market Information Limburg (RAIL) project. In this project regional labour dernand and supply forecasts have been made for the first time for one of the provinces of the Netherlands (van Eijs, de Grip, Delmee and van Loo, 1998).

Finally, attention will be given to the international context relevant to supply and demand in the Dutch labour market, which will probably become more important through the integration process of the national labour market in the European Union. First steps in this field have been undertaken in Teunis and de Grip (1996) and de Grip, Matheeuwsen and Hoevenberg (1996).

\section{NOTES}

1. The anthors are afliliatted to the Research Centre for Education and the Labour Market (ROA), Maastrich University. They thank Gerry Hughes of ESRI in Dublin; their colleagues Lex Borghans and Patrick wan Eijs; participants of the Fith IIRA European Regional Industrial Refations Congress in Dublin, 26-29 August 1997, participants of the Canadian Occupational Projections System"s FederalPProvincial Technical Conference in Otawa, 11-12 June 1998; and participants of the Workshop on Labour Market Forecasting organized by the Wissenschaftszentrum Berlin (WZB) in Berlin, 21 June 1999, for their comments on earlier versions of this chapter. 
2. See OECD (1994) and, for the approach adopted in the United Kingdom, Germany and the Netherlands in particular, Heijke (1994).

3. A comparison of ROA's forecasts with similar forecasis for other OECD countries is given by Hughes (1993), OECD (1994) and Heijke (1994).

4. For a description of the way in which ROA has defined the types of education which it differentiates, see Hejke, Matheeuwsen and Willems (2002).

5. More recent evaluation studies are available in Dutch only.

6. For the sake of convenience we assume that demand does not change.

7. This classification is compatible with the Intermational Standard Classification of Education (ISCED).

8. Apart from the substitution criterion some additional criteria are used: (1) a minumum number of 5000 workers for each type of education distinguished, for reasons of statistical reliability: (2) the classification has to be recognizable for its users (for example clusters that cover more formal levels of education are split up).

9. A comprehensive explanation can be found in van Eijs ef al. (1999). See also de Grip, Borghans and Willems (1995).

10. Borghans and Heijke (1994) have provided a detailed deseription of this model.

11. This demand refers to both expansion and replacement demand (see Figure 7.3).

12. Flow rates for male and femalle workers are different hated.

13. For more details see Willems and de Grip (1993).

14. See, for instance, van der Wiel (1999).

15. The first three effects together determine the expansion demand, whereas the passive substitution effect occurs as a result of the confrontation between supply and demand. The active substitution effect is only included in the actual development in employment (expost).

\section{REFERENCES}

Beekman, T., R. Dekker, A. de Grip and H. Heijke (1991), An explanation of the educational structure of occupations', Labour, 5 (3), $151-63$.

Blaug, M. (1967), 'Approaches to educational planning', Economic Joumal. 77 (June), 262-87.

Borghans, L. (1992), A Histo-Topographic Map of Dutch University Studies, ROAW-1992/5E, Maastricht. The Netherlands: Research Centre for Education and the Labour Market.

Borghans, L. and A. de Grip (eds) (2000), The Overeducated Worker? The Economics of Skill Utilization, Cheltenham. UK and Brookfield. USA: Edward Elgar.

Borghans, L. and H. Heijke (1994), Een random coëfficiënten model woor het voorspellen van de beroepenstructur van bedriffstakken. ROA-W-1994/1, Maastrich, The Netherlands: Research Centre for Education and the Labour Market.

Borghans, L. and H. Heike (1996), "Forecasting the educational structure of occupations: a manpower requirement approach with substitution', Labour, 10 (1), 151-92.

Borghans, L., P. van Eijs and A. de Grip (1994), An Evaluation of Labour Market Forecasts by Type of Education, ROA-R-1994/4E. Maastricht. The Netherlands: Research Centre for Education and the Labour Market.

Bresnahan, T., E. Brynjolfsson and L. Hitt (2001), "Information technology, workplace organization, and the demand for skilled labour: frm-level evidence'. Quarterly Jownal of Economics 117 (1), 339-76. 
CPB (1990), ATHENA: een bedriffstakkenmodel woor de Nederlandse economie, CPB Monografe No. 30. The Hague, The Netherlands.

Dekker, R. IJP. A. de Grip and J.A.M. Heijke (1990), An explanation of the educational structure of sectors of industry", Labour, 4 (3), 3-31.

Dekker, $\mathbb{R}$. A. de Grip and H. Heijke (1994), "Indicating the future labour market prospects of occupational groups and types of education in the Netherlands', in H. Heijke (ed.), Forecasting the Labour Market by Occupation and Education, Boston, Dordrecht and London: Kluwer Academic Publishers.

Eijs, P. wan and H. Heijke (2000), "Mismatch between occupation and education and the costs and benefits of job-related training', in H. Heijke and J. Muysken (eds), Educution and Traning in a Knowledge-Based Economy. Houndmills, London and Naw York: Macmillan, pp. 159-89.

Ej]s, P. van, A. de Grip, J. Delmee and J. van Loo (1998), De Limburgse arbeidsmarkt 1997-2002, ROA-R'-1998/3, Mastricht, The Netherlands: Research Centre for Education and the Labour Market.

Eijs, P. van, A. de Grip, B. Diephuis, A. Jacobs, P. Marey and M. de Steur (1999), Methodiek arbeids marktprognoses en -indicatoren, 1099-2004, ROA-W-1999/4, Maastricht, The Netherlands: Research Centre for Education and the Labour Market.

Grip, A. de and I.A.M. Heijke (1988), Labour Market Indicators: An Inwentory, ROA-W-1988/1E, Maastricht, The Netherlands: Research Centre for Education. and the Labour Market.

Grip, A. de and J.A.M. Heijke (1991), 'Uitwijkmogelijkheden op de arbeidsmarkt; flexibiliteit wersus produktiviteit", Onderzoek wan Onderwijs, 20 (February), $6-8$.

Grip, A. de, L. Borghans and W. Smits (1998), "Future developments in the job level and domain of high-skilled workers", in H. Heijke and L. Borghans (eds), Towands a Transparen Labour Market for Educational Decisions, Aldershot, UK. Brookfield, USA, Singapore and Sydney: Ashgate.

Grip, A. de, L. Borghans and E. Willems (1995), Methodology of the ROA Information System on Occupational Groups and Types of Education, ROA-W$1995 / 1 \mathrm{E}$, Mastriclat, The Netherlands: Research Centre for Education and the Labour Market.

Grip, A. de, L.F.M. Groot and J.A.M. Heijke (1991), 'Defining occupational groupings by educational structure', Enviromment and Planning $A, 23,59-85$.

Grip, A. de, A. Matheeuwsen and J. Hoevenberg (1996), Future Job Opportunities Wh the Europerst Union, ROA-R-1996/5E, Maastricht, The Netherlands: Research Centre for Education and the Labour Market.

Grip. A. de, P. Mejboom and E. Willems (1994), 'Vacancies, employment growth and the demand for newcomers on the labour market', in J. Muysken (ed.), Measurement and Analysis of Job Vacancies, Aldershot, UK and Brookfield, USA: Avebury, pp. 101-25.

Hartog, J. (2000), "Over-education and earnings: Where are we, where should we go?" Economics of Education Review, 19, 131-41.

Heijke, H. (ed.) (1994), Forecasting the Labour Market by Occupation and Education, Boston, Dordrecht and London: Kluwer Academic Publishers.

Meijke. $H$. and L. Borghans (1998), "Investing in education", in H. Heijke and $L$. Borghans (eds), Towards a Transparent Labour Market for Educational Decisions, Aldershot, UK, Brookfield, USA, Singapore and Sydney: Ashgate, pp. 1-18.

Heijke, H., A. Matheenwsen and E. Willems (2002), 'Clustering educational categories in a heterogeneous labour market', Education Economics, $10(3)$. 
Hughes, G. (1993), Projecting the Occupational Sirucure of Employmen in OECD Countries, OECD Labour Market and Social Policy Occasional Papers No. 10 , Paris: OECD.

Ministerie van Onderwijs, Cultur en Wetenschappen (2000), Referentieraming, Zoetermeer.

OECD (1994), Employment Ontook, July 1994, Paris: OECD.

Parnes, H.S. (1962), Forecasting Educational Needs for Economic and Social Development, Paris: OECD.

ROA (2001), De arbeidsmakt naar opleiding en beroep lot 2006, ROA-R-2001/8, Mastricht, The Netherlands: Research Centre for Education and the Labour Market.

Sanderson, J. (1987), 'Defining functional occupational groupings', Enviromment and Planning $A, 19,1199-220$.

Sheldon, S. (1985), Die berufliche und geographische Flexibilitär, Beitrage AB92, Nuremberg, Germany: Institut tür Arbeitsmarkt und Berufsforschung der Bundesanstalt für Arbeit.

Shryock, H.S and J.S. Siegel (1980), The Methods and Materials of Demography, 4th printing (rev.), Washington, DC: US Bureau of the Census, US Government Printing office.

Teulings, C. and M. Koopmanschap (1989), An econometric model of crowding out of lower education levels', European Economic Revien, 33, 1653-64.

Teunis, U. and A. de Grip (1996), International Labour Market Indicators, ROA-R1996/2E, Maastricht, The Netherlands: Research Centre for Education and the Labour Market.

Valden, R.K.W. van der and L. Borghans (1993), Competition on the Labour Market. An Analysis of the Position of Types of Traning, ROA-RM-1993/5E, Maastricht, The Netherlands: Research Centre for Education and the Labour Market.

Wiel, H.P. van der (1999), Sectoral Labour Producrivity Growth: A Growth Accounting Analysis of Dutch Indwstries, 1973-1995, CPB Onderzoeksmemorandum 158, The Hague, The Netherlands.

Wieling, M.H. and L. Borghans (2001), 'Discrepancies between supply and demand and adjustment processes in the labour market., Labour, 15 (1), 33-56.

Willems, E.JT.A. and A. de Grip (1993), 'Forecasting replacement demand by occupation and education', Inernational soumal of Fonecasting, 9, 173-85. 